\title{
Influence of Fertilizer Management on Sanded Soil and Its Response on Spatial Distribution of fine Roots
}

\author{
Huan Pablo de Souza \\ Doctor at Postgraduate Program in Forest Engineering at Federal University of Santa Maria, \\ Brazil
}

Dione Richer Momolli

PhD student at Postgraduate Program in Forest Engineering at Federal University of Santa Maria, Brazil.

E-mail: dionemomolli@gmail.com

ORCID: 0000-0003-1235-2030

Mauro Valdir Schumacher

Forest Engineer, Dr.nat.techn. Full Professor at Federal University of Santa Maria, Brazil.

Aline Aparecida Ludvichak

PhD student at Postgraduate Program in Forest Engineering at Federal University of Santa Maria, Brazil.

Angélica Costa Malheiros

Graduation in Forest Engineering at Federal University of Santa Maria, Brazil.

Claudiney Couto Guimarães

Doctor at Postgraduate Program in Forest Engineering at Federal University of Santa Maria, Brazil.

José Mateus Wisniewski Gonsalves

Futuragene Brasil Tecnologia, Itapetininga, Brazil 
Received: March 8, 2021 Accepted: April 1, $2021 \quad$ Published: April 10, 2021

doi:10.5296/jas.v9i2.18385

URL: https://doi.org/10.5296/jas.v9i2.18385

\begin{abstract}
The fine root component, although it represents the lowest proportional biomass in a tree, has an important function in obtaining water and nutrients. In addition, it is an indicator of the physiological quality and growth of a tree. Thus, the objective of the study was to evaluate the spatial distribution of biomass and the density of fine roots in five different fertilizer treatments. The five treatments received increasing amounts of fertilizers. The collections were made between trees in the planting line and between the planting lines. Soil layers of 25 $\mathrm{cm}$ x $25 \mathrm{~cm}$ x $20 \mathrm{~cm}$ (length x width x depth) were collected until reaching a depth of 1 meter. Treatments that had less nutrient input via fertilization showed higher production of fine roots. In general, the line position in the superficial layers showed a higher density of fine roots. There was significant difference between the positions of the land monoliths and between the different layers. Strategically, the lower supply of nutrients via fertilization provided greater investment in the production of fine roots by trees in order to increase the area of absorption and exploration of the soil.
\end{abstract}

Keywords: nutrient cycling, sanded soil, Eucalyptus urophylla, arenization, forestry

\title{
1. Introduction
}

Currently, the Brazilian forestry sector represents about $1.3 \%$ of the national GDP and $6.9 \%$ of the industrial GDP. Analyzing the balance of trade, difference between what is exported for what matters, in 2012 it was US \$ 5.7 billion, increasing to US \$ 11.4 billion in 2018. With more than 7.83 million hectares planted with trees, the genus Eucalyptus sp. is the most cultivated, representing $72.4 \%$ of (IBÁ, 2019).

Despite the expansion of cultivation in regions of low agricultural aptitude, it is observed that investments in research and technology have increased the average productivity from 20 $\mathrm{m}^{3} \mathrm{ha}^{-1}$ to $36 \mathrm{~m}^{3} \mathrm{ha}^{-1}$. Advances have been observed with the selection of materials suitable for edaphic and climatic conditions. However, since these are soils with low natural fertility, chemical fertilization has provided high productivity (Gonçalves et al., 2013).

The correct application of fertilizers takes into account the type, quantity, time and place of application on the plant (Barros et al., 2005). Studies that evaluate the production of fine roots and their spatial distribution in the soil can provide information for techniques of soil management, forest nutrition and fertilization. (Laclau et al., 2010).

Although root production is not the goal of the production chain, studying its behavior is fundamental. According to Gonçalves and Mello (2005), the roots can be classified as supports (thick roots) or absorption (fine roots). Usually, fine roots are classified with diameter $(<2 \mathrm{~mm})$ (Freschet et al., 2017). From a nutritional point of view, they have the 
function of absorbing and transporting water and nutrients to the plant (Pregitzer et al., 2002; Fort et al., 2017).

Typically, the spatial distribution of fine roots occurs most abundantly in topsoil (Laclau et al., 2013; Pinheiro et al., 2016.). However, Christina et al. (2011) in a study developed in Itatinga, Brazil, with the species Eucalyptus grandis at 3.5 years of age, reported the presence of fine roots up to 17 meters deep.

The biomass of fine roots in Eucalyptus sp. generally vary as $2.3 \%, 4.1 \%$, and $6.3 \%$ of the total biomass for seedlings from seeds, upper clones and lower clones, respectively (Mello et al., 1998). For Reis et al. (1985), the aerial part / roots ratio is also affected by the quality of the site. In soils with high fertility, the ratio varies between 4 and 6 , while in soils with low fertility the ratio decreases to an average of 2 .

For many researchers, fine roots are important tools for capturing and increasing water availability to trees, especially during the dry season (Christina et al., 2017; Fan et al., 2017). Even so, several physiological aspects are still incomprehensible (Maeght et al., 2013).

The present study aims to quantify fine roots production under different fertilization treatments in sanded cores.

\section{Method}

\subsection{Characterization of the Experiment}

The study was carried out in a sanded core, with exposed soil, without vegetation cover. The total sandy area covers 80 ha and is located in the municipality of Maçambará - RS, within the geographical coordinates $29^{\circ} 02.32 .67$. S and $55^{\circ} 19.40 .44$. W, at an average altitude of $191 \mathrm{~m}$ in relation to sea level.

The soil of the experimental area is classified as Entisols (Quartzipsamments), predominantly sandy texture with an average of $85.2 \%, 3.0 \%, 2.3 \%$ and $9.5 \%$ for coarse sand, fine sand, silt and clay, respectively. Regarding chemical attributes, the average organic matter content $(0.24 \%)$ up to $1 \mathrm{~m}$ deep was very low. Base saturation $(\mathrm{V})$ of $5.0 \%$ indicates that it is a dystrophic soil with low natural fertility SBCS-CQFS (2016). The soil profile presented homogeneity of the attributes analyzed between the different depths and did not present any active biological activity in the soil, nor was to the presence of roots (live or dead). Table 1 presents the physical and chemical attributes of the soil.

Seedlings of the clone (AEC 0144) of Eucalyptus urophylla were used. The soil was subsoiled at a depth of $30 \mathrm{~cm}$. The initial density was 1666 plants $\mathrm{ha}^{-1}$ with a spacing of $3 \mathrm{~m} \mathrm{x}$ $2 \mathrm{~m}$. The plots had dimensions of $60 \mathrm{~m}$ x $30 \mathrm{~m}$ with 300 individuals in each. The experiment had a completely randomized design with 5 fertilization treatments. Two $\mathrm{Mg} \mathrm{ha}^{-1}$ of dolomitic limestone were applied for all treatments and a fertilization of $150 \mathrm{~kg} \mathrm{ha}^{-1} \mathrm{of} \mathrm{K}_{2} \mathrm{O}$ in the form of chloride 30 days after planting. 
Table 1. Physical-chemical attributes of the soil in the experimental site planted with Eucalyptus urophylla in the arenized pampa biome

\begin{tabular}{|c|c|c|c|c|c|c|c|c|c|c|c|}
\hline \multirow{3}{*}{ Attribute } & \multirow{3}{*}{ Unit } & \multicolumn{10}{|c|}{ Depth (cm) } \\
\hline & & 0 & 20 & 40 & 60 & 80 & 100 & 120 & 140 & 160 & 180 \\
\hline & & 20 & 40 & 60 & 80 & 100 & 120 & 140 & 160 & 180 & 200 \\
\hline SD & $\mathrm{g} \mathrm{cm}^{-3}$ & 2.1 & 2.3 & 1.9 & 1.8 & 1.7 & 1.8 & 1.9 & 1.7 & 1.6 & 1.6 \\
\hline $\mathrm{CS}$ & & 88.0 & 88.3 & 86.0 & 81.3 & 82.3 & 84.0 & 77.6 & 81.0 & 84.0 & 82.0 \\
\hline FS & & 3.0 & 3.5 & 3.0 & 4.0 & 1.6 & 2.7 & 4.3 & 5.4 & 3.3 & 3.4 \\
\hline Silt & $\%$ & 1.0 & 1.6 & 1.0 & 3.0 & 4.7 & 2.6 & 6.0 & 2.3 & 1.4 & 3.3 \\
\hline Clay & & 8.0 & 6.6 & 10.0 & 11.6 & 11.3 & 10.6 & 12.0 & 11.3 & 11.3 & 11.3 \\
\hline O.M. & & 0.2 & 0.2 & 0.3 & 0.3 & 0.2 & 0.2 & 0.2 & 0.2 & 0.1 & 0.1 \\
\hline $\mathrm{pH}$ & $1: 2,5 \mathrm{H}_{2} \mathrm{O}$ & 4.8 & 4.7 & 4.6 & 4.6 & 4.6 & 4.6 & 4.6 & 4.7 & 4.7 & 4.6 \\
\hline $\mathrm{Al}$ & & 0.7 & 0.6 & 0.8 & 0.8 & 0.9 & 0.9 & 0.9 & 0.8 & 0.9 & 1.0 \\
\hline $\mathrm{Ca}$ & $\mathrm{cmol}_{\mathrm{c}} \mathrm{dm}^{-3}$ & 0.2 & 0.1 & 0.1 & $<0.1$ & 0.2 & 0.2 & 0.1 & $<0.1$ & 0.1 & $<0.1$ \\
\hline $\mathrm{Mg}$ & & 0.1 & $<0.1$ & $<0.1$ & $<0.1$ & 0.1 & $<0.1$ & $<0.1$ & $<0.1$ & $<0.1$ & $<0.1$ \\
\hline $\mathrm{P}^{\mathrm{a}}$ & $\mathrm{modm}-3$ & 4.6 & 3.4 & 2.3 & 2.9 & 3.5 & 4.3 & 5.0 & 6.9 & 7.3 & 6.9 \\
\hline $\mathrm{K}^{\mathrm{a}}$ & 118 काषा & 13.3 & 12.7 & 14.8 & 13.8 & 14.1 & 14.0 & 13.3 & 14.5 & 13.5 & 13.3 \\
\hline CECef & $\mathrm{cmol}_{\mathrm{c}} \mathrm{dm}^{-3}$ & 0.9 & 0.7 & 0.9 & 0.9 & 1.1 & 1.1 & 1.0 & 1.0 & 0.9 & 1.1 \\
\hline $\mathrm{CECpH}_{7}$ & & 2.6 & 2.9 & 3.6 & 3.7 & 3.8 & 3.9 & 3.8 & 3.7 & 3.8 & 3.7 \\
\hline V & $\theta$ & 7.7 & 4.6 & 4.6 & 3.2 & 4.9 & 5.1 & 3.7 & 2.6 & 2.9 & 2.5 \\
\hline M & & 77.2 & 82.1 & 81.7 & 87.0 & 82.9 & 82.3 & 86.1 & 90.4 & 88.6 & 91.3 \\
\hline$S$ & & 3.9 & 10.1 & 13.9 & 15.6 & 15.9 & 14.4 & 14.6 & 7.0 & 8.9 & 7.7 \\
\hline B & $\mathrm{mg} \mathrm{dm}^{-3}$ & 0.3 & 0.3 & 0.4 & 0.4 & 0.3 & 0.3 & 0.2 & 0.2 & 0.2 & 0.3 \\
\hline $\mathrm{Cu}$ & & 0.4 & 0.4 & 0.5 & 0.5 & 0.6 & 0.5 & 0.6 & 0.5 & 0.5 & 0.4 \\
\hline $\mathrm{Zn}$ & & 0.2 & 0.1 & 0.1 & 0.1 & 0.1 & 0.1 & 0.2 & 0.1 & 0.1 & 0.1 \\
\hline
\end{tabular}

Where: $S D=$ soil density; $C S=$ coarse sand; $F S=$ fine sand; $O . M=$ organic matter;

${ }^{a}$ Extraction method Melich I. CECef = cation exchange capacity effective; $C E C$ ef = cation exchange capacity $\mathrm{pH} 7.0 ; \mathrm{V}=$ base saturation; $m=$ aluminum saturation

The treatments received different sources and doses of fertilization. Table 2 shows the total amount applied for each element. Phosphorus dosages were used in the base fertilization. Treatments 2, 3, 4 and 5 received increasing doses of triple superphosphate, varying between $112.5-225 \mathrm{~kg} \mathrm{ha}^{-1}$. T1 was the only one to receive natural phosphate in the base fertilization. 
This application was performed in a single dose. All fertilizations were carried out manually inside pits, incorporating the fertilizer at a depth of 5 to $10 \mathrm{~cm}$ and a distance of $20 \mathrm{~cm}$ from the seedlings.

Table 2. Total amount of nutrients applied in each treatment

\begin{tabular}{|c|c|c|c|c|c|}
\hline \multirow{2}{*}{ Nutrient } & \multicolumn{5}{|c|}{ Total of nutrients $\left(\mathrm{kg} \mathrm{ha}^{-1}\right)$} \\
\hline & $\mathrm{T} 1$ & $\mathrm{~T} 2$ & $\mathrm{~T} 3$ & $\mathrm{~T} 4$ & $\mathrm{~T} 5$ \\
\hline $\mathrm{N}$ & 54.4 & 94.0 & 102.4 & 118.0 & 156.4 \\
\hline $\mathrm{P}_{2} \mathrm{O}_{5}$ & 30.0 & 96.0 & 72.0 & 84.0 & 153.0 \\
\hline $\mathrm{K}_{2} \mathrm{O}$ & 45.6 & 80.4 & 86.4 & 99.6 & 169.8 \\
\hline $\mathrm{ST}^{*}$ & - & 112.5 & 149.8 & 187.2 & 225.0 \\
\hline $\mathrm{FN}^{* *}$ & 120.6 & - & - & - & - \\
\hline $\mathrm{Ca}$ & - & 12.8 & 16.3 & 19.9 & 24.9 \\
\hline S & - & 10.3 & 13.1 & 16.0 & 20.0 \\
\hline B & - & 3.2 & 4.1 & 5.0 & 6.3 \\
\hline $\mathrm{Cu}$ & - & 1.4 & 1.8 & 2.2 & 2.8 \\
\hline $\mathrm{Mn}$ & - & 3.6 & 4.6 & 5.6 & 7.0 \\
\hline Mo & - & 0.2 & 0.2 & 0.3 & 0.4 \\
\hline $\mathrm{Zn}$ & - & 16.2 & 20.7 & 25.2 & 31.5 \\
\hline
\end{tabular}

Note: * Triple superphosphate; ** Natural phosphate

The region's climate is classified as humid Subtropical, without dry season and warm summers (Cfa). The average annual rainfall is $1916 \mathrm{~mm}$ well distributed over the months of the year. The driest month has an average rainfall $>40 \mathrm{~mm}$. The average temperature of the coldest month is $-3{ }^{\circ} \mathrm{C}$ and $<18^{\circ} \mathrm{C}$ and the temperature for the warmest month is $22^{\circ} \mathrm{C}$. (Alvares et al., 2013).

\subsection{Sampling of Fine Roots}

Three monoliths were collected in the planting line and between the planting lines in each 


\section{MInstitute Macrothink $_{\text {Inting }}$}

treatment, respectively in triplicates. Each monolith had dimensions of $25 \mathrm{~cm} \mathrm{x} 25 \mathrm{~cm}$, that is, a collection area of $0.0625 \mathrm{~m}^{2}$. The samples were collected in $20 \mathrm{~cm}$ layers until reaching 1 meter of depth. The trees were 12 months old. Figure 1 shows the collection scheme carried out within an experimental unit. Represented in (a), collection positions of fine root samples, in (b), cross section of the monolith with five layers of $20 \mathrm{~cm}$ thickness, and in (c), total dimensions of the soil monolith.

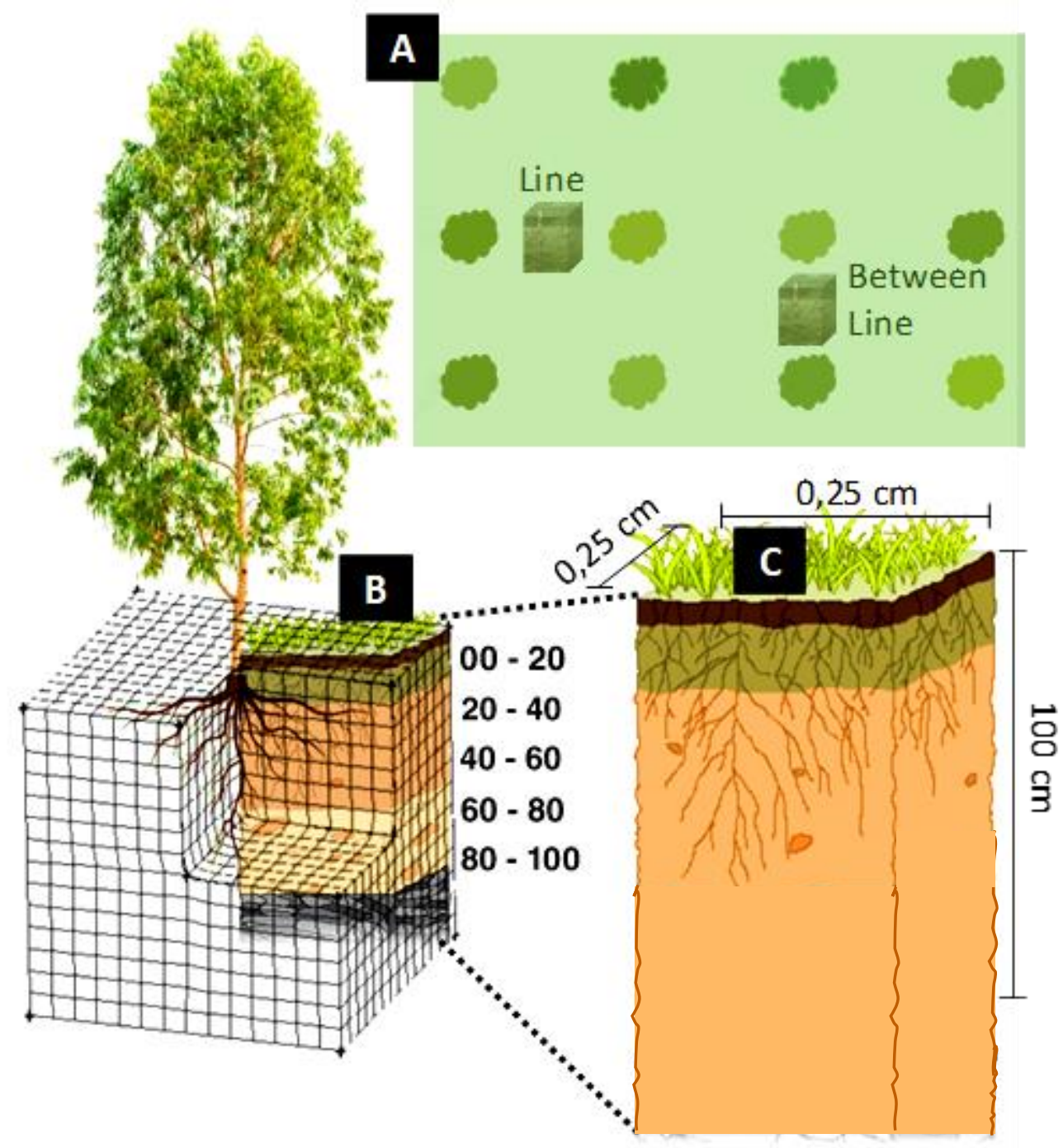

Figure 1. Scheme of collection of fine roots. (A) collection position of each monolith, (B) collection depths and $(\mathrm{C})$ dimensions of each monolith

The 150 samples were packed in plastic bags and transported to the laboratory. The first procedure for separating fine roots from the soil with a sieve. Subsequently, the remaining roots in the mesh were washed carefully and still moist, the diameters were classified with a caliper. Diameters greater than $2 \mathrm{~mm}$ were fragmented and their surpluses disregarded in the research. In an oven with renewal and forced air circulation, the samples packed in paper bags, were dried at $70{ }^{\circ} \mathrm{C}$ for 72 hours or until they reach constant weight. The weighing of the material was done with a precision scale of $0.001 \mathrm{~g}$. 


\subsection{Date Analysis}

The verification of the normal distribution of the data was through the normality test $f$ the residues (Shapiro-Wilk). Analysis of variance (ANOVA) was performed to verify for significant differences: between position of the same Treatment, between different depths of the same position and in the total amount of the fine roots between the different treatments. When the ANOVA was significant, a means test (Tukey) was performed at 5\% probability of error to know which variables differed from each other.

\section{Results}

The amount of fine roots $\left(\mathrm{kg} \mathrm{ha}^{-1}\right)$ for the depth of $0-20 \mathrm{~cm}$ in the between line position varied from 173 to $240 \mathrm{~kg} \mathrm{ha}^{-1}$ in Treatments 5 and 1 respectively. For the line position variation was 325 than $600 \mathrm{~kg} \mathrm{ha}^{-1}$ for Treatments 5 and 2 respectively. In general, as the depth increases, the amount of roots decreases. Table 3 shows the difference in means for treatments, positions and different depths.

Table 3. Amount of fine roots at different depths and positions in treatments

\begin{tabular}{|c|c|c|c|c|c|c|c|c|c|c|}
\hline \multirow{3}{*}{$\begin{array}{c}\text { Depth } \\
(\mathrm{cm})\end{array}$} & \multicolumn{10}{|c|}{ Treatment $\left(\mathrm{kg} \mathrm{ha}^{-1}\right)$} \\
\hline & \multicolumn{2}{|c|}{1} & \multicolumn{2}{|c|}{2} & \multicolumn{2}{|c|}{3} & \multicolumn{2}{|c|}{4} & \multicolumn{2}{|c|}{5} \\
\hline & B.L. & $\mathrm{L}$. & B.L. & $\mathrm{L}$. & B.L. & L. & B.L. & L. & B.L. & L. \\
\hline $0-20$ & $\begin{array}{c}240.0 \mathrm{~A} \\
\mathrm{a}\end{array}$ & $\begin{array}{c}401.6 \\
\mathrm{Aa}\end{array}$ & $\begin{array}{c}254.9 \\
\mathrm{Ab}\end{array}$ & $\begin{array}{c}600.5 \\
\mathrm{Aa}\end{array}$ & $\begin{array}{c}399.7 \mathrm{~A} \\
\mathrm{a}\end{array}$ & $\begin{array}{c}348.8 \\
\mathrm{Aa}\end{array}$ & $\begin{array}{c}220.3 \mathrm{~A} \\
\mathrm{~b}\end{array}$ & $\begin{array}{c}352.0 \\
\mathrm{Aa}\end{array}$ & $\begin{array}{c}173.3 \mathrm{~A} \\
\mathrm{~b}\end{array}$ & $\begin{array}{c}325.3 \mathrm{~A} \\
\mathrm{a}\end{array}$ \\
\hline $20-40$ & $\begin{array}{c}225.1 \mathrm{~A} \\
\mathrm{Ba}\end{array}$ & $\begin{array}{c}174.9 \\
\mathrm{Aa}\end{array}$ & $\begin{array}{c}125.6 \\
\mathrm{Ab}\end{array}$ & $\begin{array}{c}262.9 \\
\mathrm{Ba}\end{array}$ & $\begin{array}{c}125.9 \mathrm{~A} \\
\mathrm{Ba}\end{array}$ & $\begin{array}{c}144.8 \\
\mathrm{Ba}\end{array}$ & $\begin{array}{c}102.9 \mathrm{~A} \\
\mathrm{a}\end{array}$ & $85.6 \mathrm{Ba}$ & $\begin{array}{c}120.0 \mathrm{~A} \\
\mathrm{Bb}\end{array}$ & $\begin{array}{c}221.9 \mathrm{~A} \\
\mathrm{Ba}\end{array}$ \\
\hline $40-60$ & $\begin{array}{c}167.5 \mathrm{~A} \\
\mathrm{Ba}\end{array}$ & $84.8 \mathrm{Ba}$ & $\begin{array}{c}130.4 \\
\mathrm{Ab}\end{array}$ & $\begin{array}{c}205.3 \\
\mathrm{Ba}\end{array}$ & $\begin{array}{c}129.6 \mathrm{~A} \\
\mathrm{Ba}\end{array}$ & $\begin{array}{c}107.2 \\
\mathrm{Ba}\end{array}$ & $\begin{array}{c}71.5 \mathrm{~A} \\
\mathrm{Ba}\end{array}$ & 87.5Ba & $123.7 \mathrm{Ba}$ & $67.2 \mathrm{Ba}$ \\
\hline $60-80$ & $\begin{array}{c}69.3 \mathrm{AB} \\
\mathrm{a}\end{array}$ & $84.8 \mathrm{Ba}$ & $45.3 \mathrm{Ba}$ & $59.7 \mathrm{Ba}$ & $\begin{array}{c}108.3 \mathrm{~A} \\
\mathrm{Ba}\end{array}$ & $92.3 \mathrm{Ba}$ & $36.3 \mathrm{Bb}$ & 77.9Ba & $80.3 \mathrm{Ba}$ & $56.0 \mathrm{Ba}$ \\
\hline $80-100$ & $146.1 \mathrm{Ba}$ & $72.5 \mathrm{Ba}$ & $62.4 \mathrm{Ba}$ & 93.9Ba & 70.4Ba & $68.8 \mathrm{Ba}$ & $51.7 \mathrm{Ba}$ & $56.0 \mathrm{Ba}$ & $15.5 \mathrm{Bb}$ & $32.0 \mathrm{Ba}$ \\
\hline Total & 848.0 & 818.7 & 618.7 & 1222.4 & 833.9 & 761.9 & 482.7 & 658.9 & 512.8 & 702.4 \\
\hline $\begin{array}{l}\text { Avera } \\
\text { ge }\end{array}$ & 833. & & 920 & $.5 \mathrm{a}$ & 797 & $9 \mathrm{ab}$ & 570 & $.8 b$ & 607 & $.6 b$ \\
\hline
\end{tabular}

Note: $\mathrm{BL}=$ between line; $\mathrm{L}=$ line 


\section{Macrothink}

The total amount of fine roots varied between Treatments. If we consider the average of the positions in each Treatment, we can conclude that the Treatments in which they received the smallest amounts of nutrients, registered the largest amount of fine roots. Treatments 1 and 2 had an average production of 833 and $920 \mathrm{~kg} \mathrm{ha}^{-1}$ while treatments 4 and 5 had an average production of 570 and $607 \mathrm{~kg} \mathrm{ha}^{-1}$.

There was a statistical difference between the collection positions within the same Treatment. The Treatments that received the highest amounts of nutrients, differed statistically between their positions, especially in the $0-20 \mathrm{~cm}$ layer. For treatment 5 , this statistical difference can still be seen in the second layer $(20-40 \mathrm{~cm})$.

Regarding the density of fine roots, Figure 2 shows the variation in $\mathrm{g} / \mathrm{dm}^{3}$ for the different treatments between line and line positions. T2 recorded the highest density of fine roots reaching $0.3 \mathrm{~g} / \mathrm{dm}^{3}$ for the line position. The opposite behavior was observed in $\mathrm{T} 5$, which showed a density of $0.09 \mathrm{~g} / \mathrm{dm}^{3}$ in the line position.

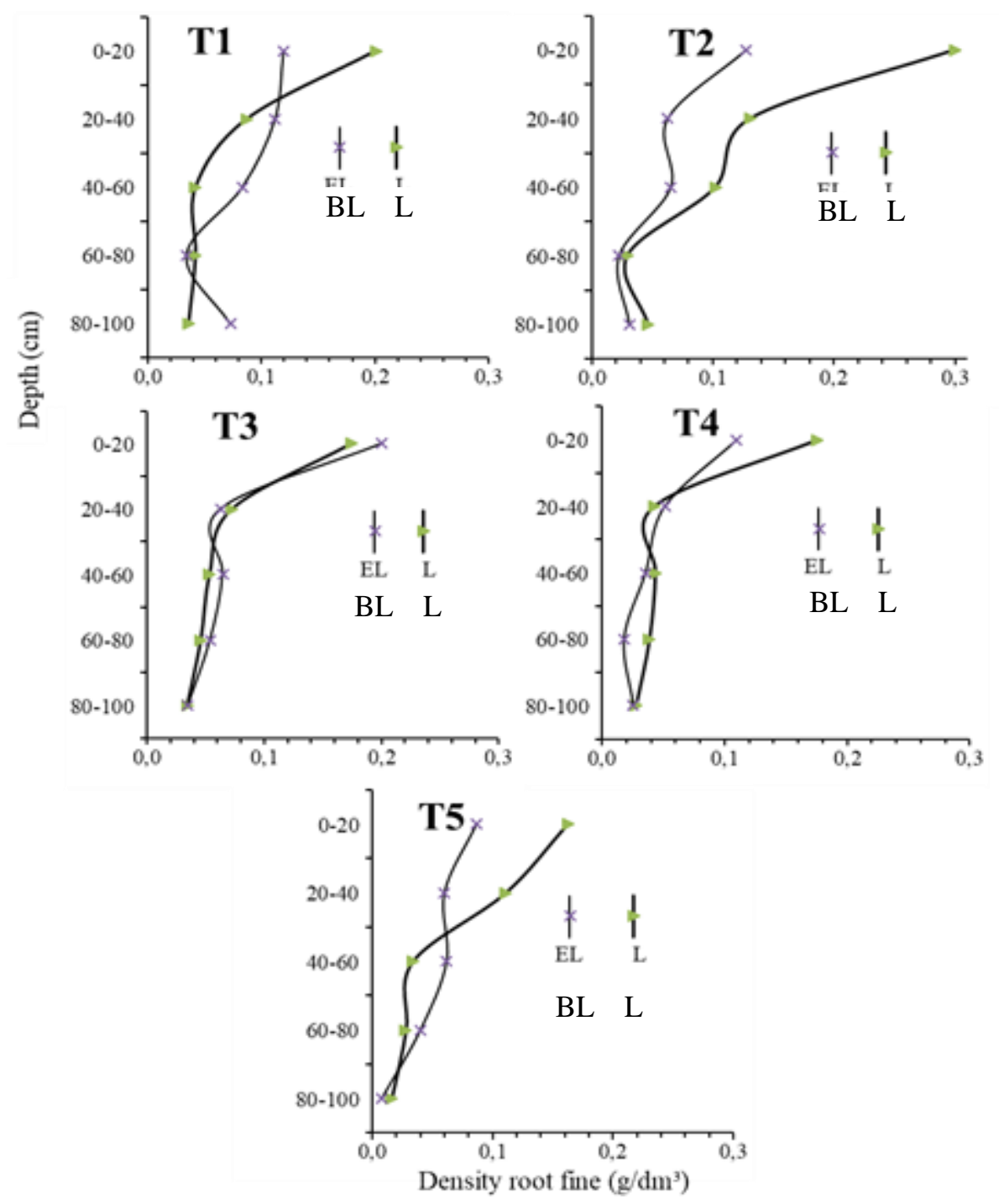

Figure 2. Density of fine roots at different depths and positions in treatments 
Figure 2 also shows that considering the layer $0-20 \mathrm{~cm}$, only for T3 the density of fine roots in the line position was lower than the line position. For all treatments the biggest differences between the collection positions occur in the 2 most superficial layers. The depths of $60-80$ and $80-100 \mathrm{~cm}$ showed similar thin root density within the same treatment.

\section{Discussion}

The inverse relationship between the number of roots and depth occurs because the topsoil represents the portion with the highest amount of nutrients. This greater nutritional offer is due in part to the chemical fertilization carried out in addition to the decomposition of litter nutrients. Another important function promoted by the litter layer is the reduction of the temperature fluctuation and possible maintenance of humidity in that layer (Macedo et al., 2014).

The amount of fine roots is also influenced, among other factors, by the texture of the soil. As shown by Lambais (2015) in a study carried out in an Oxisol of different textural class, the more sandy the soil, the greater the capacity for development and growth of fine roots. The root length in the 0 - $30 \mathrm{~cm}$ layer of 2-year-old Eucalyptus grandis trees in $20 \%$ clay soil was double that observed in $40 \%$ clay soil.

Although the textural class of the soil is an important factor, the fertility of the soil needs to be considered. Assessing the production of fine roots in Eucalyptus dunnii stands at 16 months of age, Dick et al. (2019) showed a stock of $727 \mathrm{~kg} \mathrm{ha}^{-1}$ for layer $0-20 \mathrm{~cm}$ of soil. This value was much higher than that found in the present study. For line position to the highest value was $600 \mathrm{~kg} \mathrm{ha}^{-1}$ at T2 and $325 \mathrm{~kg} \mathrm{ha}^{-1}$ at T5. Dick et al. (2019) found an organic matter of the soil of $1.4 \%$ for the respective layer, while for the present study it was only $0.2 \%$. This can explain the lower production of fine roots.

Although the highest density of fine roots $\mathrm{g} / \mathrm{dm}^{3}$ is observed in $\mathrm{T} 2$, the average for depth 0 $20 \mathrm{~cm}$ in all positions and treatments was $0.16 \mathrm{~g} / \mathrm{dm}^{3}$. Assessing the depth $0-20 \mathrm{~cm}$ in Eucalyptus dunnii stands at 16 months, Dick et al. (2019) found an average fine root density of $0.36 \mathrm{~g} / \mathrm{dm}^{3}$. Part of the results are due to age of the stand. Another relevant factor is the organic matter content, which in turn allows greater water retention capacity and development of the root system.

Studying the behavior of fine roots in Eucalyptus grandis from 2 to 4 years of age, Lambais et al. (2017) found that the greatest growth in length in the topsoil occurred in the warm and wet seasons. These results help to explain the lower density observed in this study when compared to those in the literature. Predominantly sandy soils have low water retention rates (Mezzomo et al., 2018), Sandy soils as in the present study compromise the survival of fine roots during periods of low rainfall.

The density of fine roots in the stand of the hybrid Eucalyptus urophylla x Eucalyptus grandis at 59 months after planting was evaluated by Macana et al. (2020). The authors concluded that the root density decreases gradually along the soil profile. For depth $0-25 \mathrm{~cm}$ the density was $0.32 \mathrm{~g} / \mathrm{dm}^{3}$ with the clone susceptible to water stress and the addition of gypsum. Germon et al. (2018) found an average density at depth $0-50 \mathrm{~cm}$ of $0.32 \mathrm{~g} / \mathrm{dm}^{3}$ in Eucalyptus grandis stands. The findings are above the average of the values found for the 
treatments in the present study. The evaluation by the authors was carried out 4 years after the implantation of the stand. This allowed a development of the root system, proportional to the biomass above ground.

\section{Conclusion}

There was an influence of fertilization on the pattern of development of fine roots. The treatments that received the lowest amounts of fertilizers showed the highest amount and density of fine roots. This behavior is a strategy on the part of the plant in order to explore a greater volume of soil, supplying the plant's physiological demands with water and nutrients.

The statistical analysis also pointed out a significant difference between positions of the same treatment. With that it is concluded that the nutritional contribution in the planting line was positive in the development of the roots and possibly of the aboveground biomass.

An inverse relationship between depth and thin roots was found. Fertility in the superficial layers allowed for greater root development, gradually decreasing with depth.

\section{References}

Alvares, C. A., Stape, J. L., Sentelhas, P. C., Gonçalves, J. L. M., \& Sparovek, G. (2013). Köppen.s climate classification map for Brazil. Meteorologische Zeitschrift, https://doi.org/10.1127/0941-2948/2013/0507

Barros, N. F., Neves, J. C. L., \&Novais, R. F. (2005). Recomendação de fertilizantes minerais em plantios de eucalipto, p.135-165. In: Gonçalves, J. L. M.; Benedetti. (Eds.). Nutrição e fertilização florestal. v.2. Instituto de Pesquisas Florestais, Piracicaba, São Paulo.

Christina, M., Laclau, J. P., Goncalves, J. L. M., Jourdan, C., Nouvellon, Y., \& Bouillet, J. P. (2011). Almost symmetrical vertical growth rates above and below ground in one of the world's most productive forests. Ecosphere. https://doi.org/10.1890/ES10-00158.1

Christina, M., Nouvellon, Y., Laclau, J. P., Stape, J. L., Bouillet, J. P., Lambais, G. R., \& Maire, G. (2017). Importance of deep water uptake in tropical eucalypt forest. Funct. Ecol., 31, 509-519. https://doi.org/10.1111/1365-2435.12727

Dick, G., \& Schumacher, M. V. (2019). Raizes finas em árvores jovens de Eucalyptus dunnii Maiden. Ecologia e Nutrição Florestal, 7e03. https://doi.org/10.5902/2316980X36338

Fan, Y., Miguez-Macho, G., Jobbágy, E. G., Jackson, R. B., \& Otero-Casal, C. (2017). Hydrologic regulation of plant rooting depth. Proc. Natl. Acad. Sci., 114(40), 10572-10577. https://doi.org/10.1073/pnas.1712381114

Fort, F., Volaire, F., Guilioni, L., Barkaoui, K., Navas, M. L., \& Roumet, C. (2017). Root traits are related to plant water-use among rangeland Mediterranean species. Funct. Ecol., 31, 1700-1709. https://doi.org/10.1111/1365-2435.12888

Freschet, G. T., Valverde-Barrantes, O. J., Tucker, C. M., Craine, J. M., Mccormack, M. L., Violle, C., ... Roumet, C. (2017). Climate, soil and plant functional types as drivers of global fine-root trait variation. J. Ecol., 105, 1182-1196. https://doi.org/10.1111/1365-2745.12769 
Germon, A., Guerrini, I. A., Bordron, B. et al (2018). Consequences of mixing Acacia mangium and Eucalyptus grandis trees on soil exploration by fine-roots down to a depth of 17 m. Plant Soil, 424, 203-220. https://doi.org/10.1016/j.foreco.2019.05.010

Gonçalves, J. L. D. M., Alvares, C. A., Higa, A. R., Silva, L. D., Alfenas, A. C., Stahl, J., ... Epron, D. (2013). Integrating genetic and silvicultural strategies to minimize abiotic and biotic constraints in Brazilian eucalypt plantations. Forest Ecol. Manage. 301, 6-27. https://doi.org/10.1016/j.foreco.2012.12.030

Gonçalves, J. L. M., \& Mello, S. L. M. (2005). O sistema radicular das árvores. In: Gonçalves, J. L. M.; Benedetti. (Eds.). Nutrição e fertilização florestal. v.2. Instituto de Pesquisas Florestais, Piracicaba, São Paulo.

IBÁ. (2019). Indústria Brasileira de Árvores. Relatório 2019. Brasília, 2019. 534 p.

Laclau, J. P., da Silva, E. A., Rodrigues Lambais, G., Bernoux, M., Le Maire, G., Stape, J. L., ... Nouvellon, Y. (2013). Dynamics of soil exploration by fine roots down to a depth of 10 $\mathrm{m}$ throughout the entire rotation in Eucalyptus grandis plantations. Front. Plant Sci., 243, 1-12. https://doi.org/10.3389/fpls.2013.00243

Laclau, J. P., Ranger, J., de Moraes Gonçalves, J. L., Maquère, V., Krusche, A. V., M'Bou, A. T., ... Deleporte, P. (2010). Biogeochemical cycles of nutrients in tropical Eucalyptus plantations. Main features shown by intensive monitoring in Congo and Brazil. Forest Ecol. Manage. 259, 1771-1785. https://doi.org/10.1016/j.foreco.2009.06.010

Lambais, G. R. (2015). Produção e mortalidade de raízes finas em plantações de Eucalyptus grandis cultivados em Latossolos (Itatinga-SP). 139 p. Tese (Doutorado). Centro de Energia Nuclear na Agricultura, Universidade de São Paulo, Piracicaba, 2015.

Lambais, G. R. et al (2017). Contrasting phenology of Eucalyptus grandis fine roots in upper and very deep soil layers in Brazil. Plant Soil, 421, 301-318. https://doi.org/10.1007/s11104-017-3460-1

Macana, Y. A. M., Toledo, F. H. S. F., Ferraz, A. V. et al (2020). Soil fertility and fine root distribution after gypsum application in Eucalyptus plantations with different tolerance to water deficit. New Forests. https://doi.org/10.1007/s11056-020-09773-7

Macedo R. L. G. et al (2014). Plasticidade Ecofisiológica. In: VALE, A.B. et al. Eucaliptocultura no Brasil: Silvicultura, manejo e ambiência. Viçosa, MG, SIF. 551p.

Maeght, J. L., Rewald, B., \& Pierret, A. (2013). How to study deep roots-and why it matters. Front. Plant Sci. 4, 1-14. https://doi.org/10.3389/fpls.2013.00299

Mello, S. L.M., Gonçalves, J. L. M., \& Oliveira, L. E. G. (1998). Características do sistema radicular em povoamentos de eucaliptos propagados por sementes e estacas. Scientia Forestalis, 54, 16-26.

Mezzomo, W., Robaina, A. D., Peiter, M. X., Kirchner, J. H., Torres, R. R.. \& Ben, L. H. B. (2018). Comparação dos modelos de Campbell e de Van Genuchten para a determinação da 


\section{Macrothink}

Journal of Agricultural Studies

ISSN 2166-0379 2021, Vol. 9, No. 2

curva de retenção de água em diferentes solos. Rev. Bras. Agric. Irr. 12, 1, p. 2395 - 2405. https://doi.org/10.7127/rbai.v12n100739

Pinheiro, R. C., de Deus, J. C., Nouvellon, Y., Campoe, O. C., Stape, J. L., Aló, L. L., ... Laclau, J. P. (2016). A fast exploration of very deep soil layers by Eucalyptus seedlings and clones in Brazil. Forest Ecol. Manage. 366, 143-152. https://doi.org/10.1016/j.foreco.2016.02.012

Pregitzer, K. S., DeForest, J. L., Burton, A. J., Allen, M. F., Ruess, R. W., \& Hendrick, R. L. (2002). Fine root architecture of nine North American trees. Ecol. Monographs 72, 293-309. https://doi.org/10.2307/3100029

Reis, M. G. F., Kimmins, J. P., Rezende, G. C., \& Barros, N. F. (1985). Acúmulo de biomassa em uma sequência de idade de Eucalyptus grandis plantado no cerrado em duas áreas com diferentes produtividades. Revista Árvore, 9(2), 149-162.

SBCS-CQFS. Sociedade Brasileira de Ciência do Solo-Comissão de Química e Fertilidade do Solo. RS/SC. Manual de calagem e adubação para os Estados do Rio Grande do Sul e de Santa Catarina. $11^{a}$ ed. Solo. Núcleo Regional Sul. Porto Alegre. 2016, 376 p.

\section{Copyright Disclaimer}

Copyright for this article is retained by the author(s), with first publication rights granted to the journal.

This is an open-access article distributed under the terms and conditions of the Creative Commons Attribution license (http://creativecommons.org/licenses/by/4.0/). 